\title{
Genistein treatment increases bone mass in obese, hyperglycemic mice
}

This article was published in the following Dove Press journal:

Diabetes, Metabolic Syndrome and Obesity:Targets and Therapy

15 March 2016

Number of times this article has been viewed

\section{Richard M Michelin' \\ Layla Al-Nakkash ${ }^{2}$ \\ Tom L Broderick ${ }^{3}$ \\ Jeffrey H Plochocki ${ }^{4}$}

'Arizona College of Osteopathic Medicine, ${ }^{2}$ Department of Physiology, ${ }^{3}$ Laboratory of Diabetes and Exercise Metabolism, Department of Physiology, ${ }^{4}$ Department of Anatomy, Arizona College of Osteopathic Medicine, Midwestern University, Glendale, AZ, USA
Correspondence: Jeffrey H Plochocki Department of Anatomy, Arizona College of Osteopathic Medicine, Midwestern University, Glendale, AZ 85308, USA

$\mathrm{Tel}+\mathrm{I} 6235723715$

Fax +l 6235723679

Email jploch@midwestern.edu
Background: Obesity and type 2 diabetes mellitus are associated with elevated risk of limb bone fracture. Incidences of these conditions are on the rise worldwide. Genistein, a phytoestrogen, has been shown by several studies to demonstrate bone-protective properties and may improve bone health in obese type 2 diabetics.

Methods: In this study, we test the effects of genistein treatment on limb bone and growth plate cartilage histomorphometry in obese, hyperglycemic ob/ob mice. Six-week-old ob/ob mice were divided into control and genistein-treated groups. Genistein-treated mice were fed a diet containing $600 \mathrm{mg}$ genistein/ $\mathrm{kg}$ for a period of 4 weeks. Cross-sectional geometric and histomorphometric analyses were conducted on tibias.

Results: Genistein-treated mice remained obese and hyperglycemic. However, histomorphometric comparisons show that genistein-treated mice have greater tibial midshaft diameters and ratios of cortical bone to total tissue area than the controls. Genistein-treated mice also exhibit decreased growth plate thickness of the proximal tibia.

Conclusion: Our results indicate that genistein treatment affects bone of the tibial midshaft in the ob/ob mouse, independent of improvements in the hyperglycemic state and body weight.

Keywords: obesity, hyperglycemia, genistein, ob/ob mice, bone

\section{Introduction}

More than one-third of US adults are obese. ${ }^{1}$ According to the Centers of Disease Control and Prevention, obesity-related conditions such as hypertension, heart disease, cancer, and type 2 diabetes mellitus (T2DM) are listed as the leading causes of preventable death. Obesity is also a significant risk factor for the development of diseases that affect the skeleton, such as T2DM. In a report by the World Health Organization, $\sim 85 \%$ of patients with T2DM were found to be obese. Patients with T2DM also have elevated rates of limb bone fractures, even when controlling for weight and other risk factors. ${ }^{2-5}$ T2DM-related loss of cortical limb bone without sufficient compensatory growth of cancellous bone reduces limb bone resistance to bending and elevates bone fracture prevalence in the T2DM population. ${ }^{6,7}$

The relationship between obesity-related T2DM and skeletal health is multifaceted. One important influence on this relationship is leptin, an adipokine released in response to insulin that helps regulate adipose and bone metabolism. ${ }^{8,9}$ Leptin resistance due to hyperleptinemia has been implicated in the pathophysiology of insulin resistance and obesity-related T2DM. ${ }^{10-14}$ Following onset, obese adolescents and obese females with T2DM display significant relative hypoleptinemia in comparison with obese individuals without T2DM. ${ }^{15,16} \mathrm{Ob} / \mathrm{ob}$ mice that have a mutation in the gene encoding leptin display 
elevated insulin levels and T2DM-like hyperglycemia, as well as decreased cortical bone mass and size. ${ }^{17,18} \mathrm{Ob} / \mathrm{ob}$ leptindeficient mice also exhibit reduced metabolism of epiphyseal plates during growth. ${ }^{19}$ Further confirming the role of leptin in the maintenance of bone health is the observation that leptin administration decreases the presence of adipocytes in rodent bone marrow, leading to a reduced production of inflammatory cytokines that promote osteoclastogenesis, thereby promoting bone formation and the maintenance of bone mass. ${ }^{20}$ Thus, increased fracture risk associated with T2DM could, in part, be related to the role that leptin plays in skeletal tissue health and maintenance.

It is well documented that estrogen replacement therapy (ERT) has been effective in reducing or reversing postmenopausal bone loss and in reducing the risk of osteoarthritis (OA). ${ }^{21-24}$ Although the exact mechanisms are still unclear, it has been suggested that estrogen may interact in an indirect fashion with leptin to affect fat utilization. ${ }^{25}$ However, recent studies have shown that ERT is correlated with increased risk of breast, ovarian, and endometrial cancers, as well as cardiovascular disorders. ${ }^{26,27}$ Genistein is a phytoestrogen found in soybean products currently being studied as a potential alternative treatment to ERT due to its reported positive effects on postmenopausal depression, bone metabolism, and tumor growth, as well as its use as a dietary supplement to attenuate symptoms of menopause. ${ }^{28-31}$ Several studies have raised concerns about the effectiveness of genistein treatment on postmenopausal bone maintenance and the relationship of genistein treatment with cancer risk and other health problems, while others suggest that genistein increases bone mineral density (BMD), and any deleterious effects are related to age and dose dependent or drug interactions with cancer interventions. ${ }^{32-36}$ Longitudinal studies lasting a year or more have shown that genistein treatment may exhibit tumor-suppressing qualities, does not alter the expression of the breast cancer susceptibility genes, and may decrease the prevalence of chromosomal aberrations, along with other health benefits. ${ }^{32,37-40}$

Structurally, genistein resembles estrogen and can bind to estrogen receptors with an affinity 100- to 1,000-fold less than that of estradiol. ${ }^{41}$ While the mechanism of action of genistein on bone is not yet fully understood, its positive effects on bone are most likely a direct result of greater binding affinity for ER- $\alpha$ compared with ER- $\beta$, leading to the mineralization phase of bone formation. ${ }^{42,43}$ With previous animal studies demonstrating increased BMD and increased bone fracture strength with genistein treatment, as well as clinical studies demonstrating increased BMD in postmenopausal women with phytoestrogen treatment, it can be presumed that genistein, when ingested, aids in the regulation of bone formation and resorption. ${ }^{44-50}$ In addition to increased bone loss and fracture risk, diabetes has also been linked to OA. OA is a degenerative disease characterized by the loss of collagens and proteoglycans as the main structural molecules of articular cartilage. ${ }^{51}$ There has yet to be conclusive evidence labeling diabetes as a risk factor for OA; however, obesity has shown to be a risk factor for both conditions, highlighting the need for interventions that can address both OA and diabetes. Epidemiological studies have shown that the prevalence, incidence, symptoms, and severity of OA increase after menopause and are more severe in women. ${ }^{52-55}$ These findings indicate a common relationship between $\mathrm{OA}$ and estrogen and suggests that genistein treatment could be beneficial to the health of cartilage.

To the best of our knowledge, genistein as a dietary treatment to counteract the negative effects on bone and cartilage seen in obese individuals with T2DM has yet to be explored. The aim of this study is to investigate the effects of genistein treatment on tibial bone remodeling in female leptin-deficient ob/ob mice, which exhibit the type 2 diabetic phenotype.

\section{Methods}

\section{Animals}

The study utilized female ob/ob mice (B6.V-Lep/J) purchased from Jackson Laboratory (Bar Harbor, ME, USA) at 4-5 weeks of age. These mice display leptin deficiency, severe obesity, hyperinsulinemia, and hyperglycemia in a phenotype similar to human patients with T2DM. All mice consumed food and water ad libitum and were housed in an animal facility maintained at a room temperature of $22^{\circ} \mathrm{C}$ with a 12-hour light/dark cycle. Body weight was measured weekly during the study, and the general health was monitored biweekly. The Institutional Animal Care and Use Committee at Midwestern University approved the study. Animal care followed the guidelines set forth in the National Institutes of Health's The Guide for the Care and Use of Laboratory Animals published in 2011.

\section{Study design}

We followed the methodology previously described by Al-Nakkash et al. ${ }^{56}$ Briefly, mice were randomly assigned to a genistein-containing or standard rodent diet for a period of 4 weeks. The genistein-treated group consisted of ten mice, and the control group consisted of nine mice; one tibia was excluded due to fracture during the embedding process. The specially formulated genistein-containing diet was prepared 
in powder form by Dyets Inc., (Bethlehem, PA, USA), which contains $600 \mathrm{mg}$ genistein $/ \mathrm{kg}$. Diets had an energy content estimate of $16.28 \mathrm{~kJ} / \mathrm{g}$ and contained $20.3 \mathrm{~g}$ protein, $66 \mathrm{~g}$ carbohydrate, and $5 \mathrm{~g}$ fat. Mice were allowed to eat ad libitum. Genistein at the concentration of $600 \mathrm{mg} / \mathrm{kg}$ was chosen due to its high bioavailability and maintenance of plasma concentrations comparable to those of soy-based human diets. This is based on earlier work demonstrating that genistein in humans is readily absorbed, with genistein concentrations in plasma of $\sim 2 \mu \mathrm{mol} / \mathrm{L} .{ }^{57-59}$ Furthermore, it has previously been reported that the consumption of $750 \mathrm{mg} / \mathrm{L}$ genistein also generates plasma genistein concentrations of $\sim 2 \mu \mathrm{mol} / \mathrm{L}$ in mice. ${ }^{60}$ Mice were monitored during the experiment, and no mice exhibited distress indicative of treatment intolerance. After 4 weeks of dietary treatment, mice were sacrificed with $\mathrm{CO}_{2}$ asphyxiation followed by bilateral pneumothorax, and the hind limb bones were dissected. Blood was collected and centrifuged at $14,500 \mathrm{rpm}$ for 5 minutes, stored at $-80^{\circ} \mathrm{C}$, and later analyzed for glucose using a commercially available kit (Autokit Glucose; Wako Pure Chemical Industries, Osaka, Japan).

\section{Cross-sectional geometry of the tibia}

Following sacrifice, tibias were collected, cleaned, and measured using a digital caliper. Tibias were fixed in formalin, dehydrated in $70 \%$ and $85 \%$ alcohol, and cleared using Histoclear (National Diagnostics, Atlanta, GA, USA), with each step involving two changes 24 hours apart. Infiltration step 1 was performed using Osteo-Bed Resin A, two changes 48 hours apart.

Infiltration step 2 was performed using Catalyzed OsteoBed Resin (100 mL Osteo-Bed Resin A, 1.40 g benzoyl peroxide), two changes 48 hours apart. Embedding solution (100 mL Osteo-Bed Resin A, 3.5 g benzoyl peroxide) was prepared ahead of time. Small amounts were poured into 19 vials that were then placed in a bead bath maintained at $32^{\circ} \mathrm{C}$ for 48 hours. After polymerization, tibias were removed from infiltration, marked at the midshaft, placed in each vile, and covered with embedding solution. The samples were again placed in a bead bath maintained at $32^{\circ} \mathrm{C}$ for 48 hours to polymerize. A single transverse section was taken at the midshaft of the tibias with an Isomet low-speed saw (Buehler, Lake Bluff, IL, USA). The sections were manually ground to a thickness of $75 \mu \mathrm{m}$ and digitally captured under microscopy at $4 \times$ magnification using a Nikon Eclipse 55i (Nikon Instruments, Melville, NY, USA). Histomorphometric properties of bone were calculated using the ImageJ v1.44 plugin MomentMacroJ (authored by M
Warfel and revised by S Serafin). These properties included the minimum and maximum second areas of moment $\left(I_{\text {min }}\right.$ and $I_{\max }$, respectively), polar moment of area $(J)$, and area of cortical bone (CtAr). These cross-sectional geometric data are indicative of a bone's ability to resist deforming under mechanical loading. CtAr measures resistance to compressive loading, $I_{\min }$ and $I_{\max }$ measure resistance to bending loads in the minor and major axes, respectively, and $J$ approximates torsional rigidity. Body mass, maximum radius (MaxRad), periosteal perimeter ( $\mathrm{PsPm})$, endosteal perimeter (EsPm), the location of the geometric mean on the $\mathrm{X}$-axis $\left(\mathrm{X}_{\mathrm{bar}}\right)$ and Y-axis $\left(\mathrm{Y}_{\mathrm{bar}}\right)$, medullary area (MAr), total area of the crosssection (TtAr), ratios of cortical area to total area of the cross-section (CtAr/TtAr), and marrow area relative to the total area (MAr/TtAr) were recorded as well.

\section{Histomorphometry of the tibia}

After the mice were sacrificed, tibia bones were dissected free of soft tissue and tibial length was measured with a digital caliper. The proximal half of the tibias were decalcified and fixed (Surgipath Decalcifier I; Surgipath Medical Industries, Grayslake, IL, USA) for 4 days. Once decalcified, liquid nitrogen was used to snap-freeze the tibias, and $12 \mu \mathrm{m}$-thick coronal sections were made using a cryostat. After staining with aqueous fast green and toluidine blue (Sigma-Aldrich, Co., St Louis, MO, USA), the sections were digitally captured at 40× magnification (Nikon Instruments). Thickness of the growth plate and the calcified growth plate layer were measured in the middling of the joint using ImageJ.

\section{Statistics}

Data were shown as mean \pm standard error. The $t$-tests were used to identify significant differences between treatment groups. Kolmogorov-Simonov test for normality and Levene's tests of homogeneity of the variances were used to ensure assumptions of the $t$-tests were not violated. Cross-sectional geometric comparisons were adjusted for body mass. SPSS 19 was used for all statistical analyses (StataCorp LP, College Station, TX, USA). Values of $P<0.05$ were considered significant.

\section{Results \\ Genistein does not affect body mass or serum glucose}

While the genistein-treated mice had lower body mass overall in comparison with the control group, the difference was not significant $(P=0.06)$. Genistein-treated mice had serum glucose levels that were $12.9 \%$ lower than controls, 

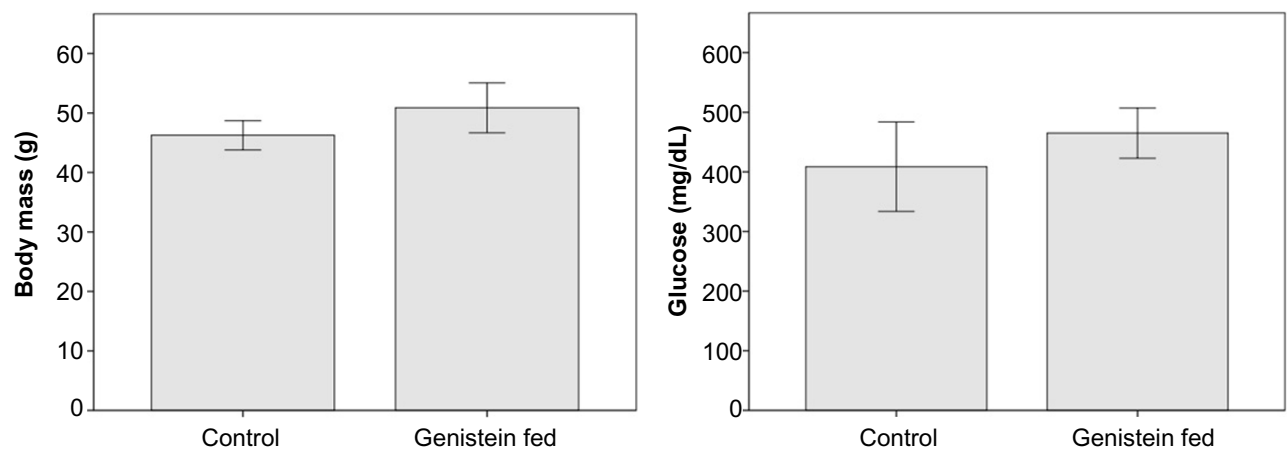

Figure I The effects of genistein treatment on body mass and serum glucose in ob/ob mice.

Notes: There was no difference between control and genistein-fed mice in body mass (50.9 $\pm 2.1 \mathrm{~g}$ and $46.3 \pm 1.2 \mathrm{~g}$, respectively, $P=0.06)$ or serum glucose in control $(465.1 \pm 22.1 \mathrm{mg} / \mathrm{dL}$ and $408.7 \pm 37.5 \mathrm{mg} / \mathrm{dL}$, respectively, $P=0.22)$. Data are shown as mean $\pm 2 \mathrm{SE}$.

Abbreviation: SE, standard error.

but again this difference was not statistically significant $(P=0.22$, Figure 1$)$.

\section{Genistein treatment increased bone mass of the tibia}

Genistein treatment had no effect on tibial length (Table 1). Nor did genistein treatment affect CtAr, $I_{\text {max }}, I_{\text {min }}, J$, or the periosteal and endosteal perimeters. However, CtAr/TtAr and MaxRad were significantly elevated in genistein-treated mice in comparison with controls $(P<0.05)$. MAr was also not significantly elevated or decreased, but MAr/TtAr was significantly reduced in genistein-treated mice in comparison with controls $(P<0.05)$. $\mathrm{X}_{\text {bar }}$ was not significantly different

Table I The effects of genistein treatment on cross-sectional geometric properties of the tibial midshaft in ob/ob mice

\begin{tabular}{|c|c|c|c|}
\hline & $\begin{array}{l}\text { Control } \\
(n=9)\end{array}$ & $\begin{array}{l}\text { Treated } \\
(n=10)\end{array}$ & $P$-value \\
\hline Tibial length (mm) & $16.7 \pm 0.11$ & $16.53 \pm 0.12$ & 0.41 \\
\hline$I_{\max }\left(\mathrm{mm}^{4} \times 10^{-2}\right)$ & $4.78 \pm 0.33$ & $4.96 \pm 0.25$ & 0.67 \\
\hline$I_{\min }\left(\mathrm{mm}^{4} \times 10^{-2}\right)$ & $4.30 \pm 0.33$ & $4.47 \pm 0.24$ & 0.70 \\
\hline$J\left(\mathrm{~mm}^{4} \times 10^{-2}\right)$ & $9.08 \pm 0.67$ & $9.47 \pm 0.48$ & 0.64 \\
\hline $\operatorname{MaxRad}(\mathrm{mm})$ & $1.00 \pm 0.20$ & $1.22 \pm 0.08$ & 0.05 \\
\hline$X_{\text {bar }}$ & $0.7 I \pm 0.08$ & $0.82 \pm 0.20$ & 0.21 \\
\hline$Y_{\text {bar }}$ & $0.70 \pm 0.15$ & $0.89 \pm 0.19$ & 0.03 \\
\hline PsPm (mm) & $3.25 \pm 0.06$ & $3.29 \pm 0.12$ & 0.78 \\
\hline EsPm (mm) & $2.27 \pm 0.20$ & $2.20 \pm 0.21$ & 0.52 \\
\hline $\operatorname{CtAr}\left(\mathrm{mm}^{2}\right)$ & $0.73 \pm 0.03$ & $0.75 \pm 0.02$ & 0.53 \\
\hline $\operatorname{MAr}\left(\mathrm{mm}^{2}\right)$ & $0.7 I \pm 0.02$ & $0.70 \pm 0.02$ & 0.76 \\
\hline $\operatorname{TtAr}\left(\mathrm{mm}^{2}\right)$ & $1.44 \pm 0.05$ & $1.46 \pm 0.04$ & 0.84 \\
\hline $\mathrm{CtAr} / \mathrm{TtAr}(\%)$ & $50.5 \pm 0.44$ & $51.7 \pm 0.34$ & 0.05 \\
\hline MAr/TtAr (\%) & $49.4 \pm 0.43$ & $48.3 \pm 0.33$ & 0.05 \\
\hline
\end{tabular}

Notes: Values are expressed as mean \pm SE. Bold values represent statistically significant $P$-values.

Abbreviations: MaxRad, maximum radius; PsPm, periosteal perimeter; EsPm, endosteal perimeter; CtAr, cortical area; TtAr, total area of the cross-section; MAr, medullary area; SE, standard error; $I_{\max }$, maximum second area of moment; $I_{\text {min }}$, minimum second area of moment; J, polar moment of inertia; $X_{b a r}, X$-axis geometric mean; $\mathrm{Y}_{\text {bar }}, \mathrm{Y}$-axis geometric mean. between treatment groups, but $Y_{\text {bar }}$ was found to be significantly greater in genistein-treated mice $(P<0.05)$, indicating a change in location of the geometric mean of the sections.

\section{Genistein treatment decreases growth plate thickness in the proximal femur}

Figure 2 shows micrographs of proximal tibial growth plates of control and genistein-fed mice. Growth plate thickness in genistein-treated mice was found to be significantly smaller in comparison with control mice $(P<0.05)$. Genistein treatment had no effect on calcified cartilage thickness (Figure 3).

\section{Discussion}

Earlier studies on the effect of leptin on skeletal tissue were inconsistent; however, a clearer picture is emerging that suggests leptin increases the expression of genes that promotes bone formation and decreases the expression of genes that promotes resorption of bone. ${ }^{10,61-65}$ As a result, leptin-deficient ob/ ob mice exhibit reductions in bone mass and bone formation

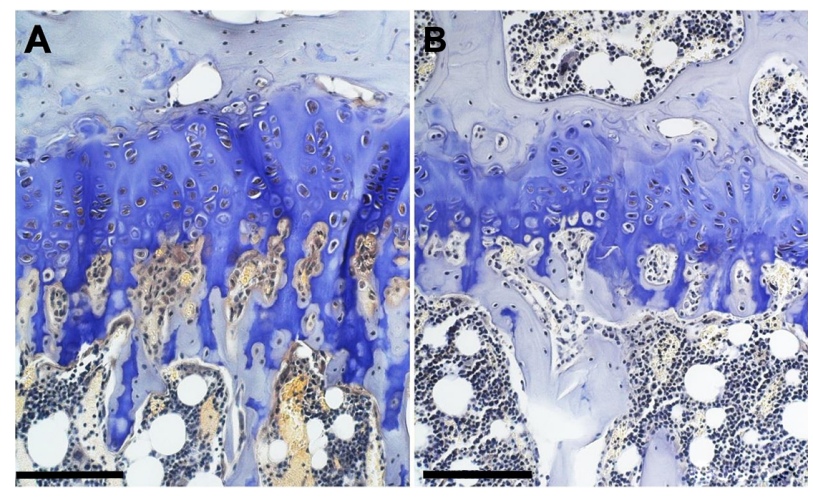

Figure 2 Micrographs of the proximal tibial growth plate of $(\mathbf{A})$ control and (B) genistein-fed ob/ob mice.

Notes: Scale bar is $100 \mu \mathrm{m}$. Toluidine blue and aqueous fast green stains were used, $40 \times$ magnification. 


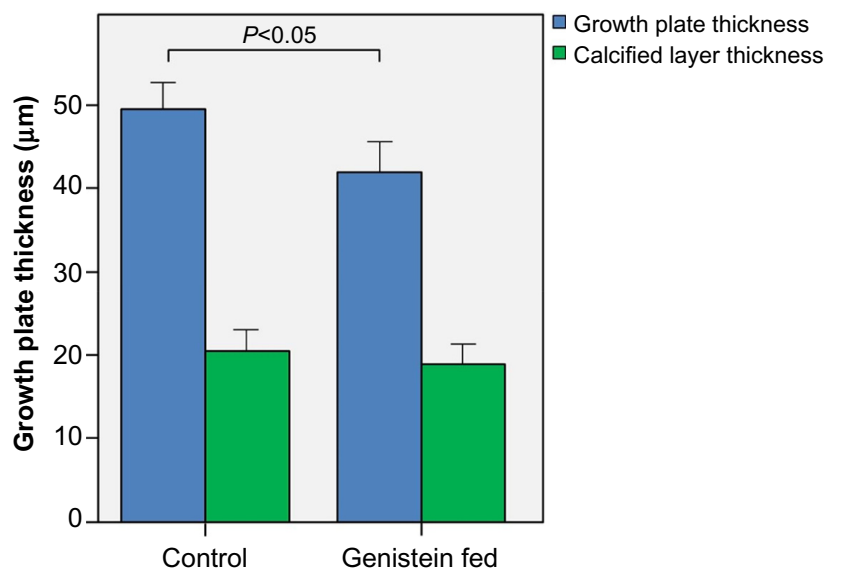

Figure 3 Growth plate thickness in control and genistein fed mice.

Notes: Growth plate thickness was significantly reduced in genistein-treated mice $(42.7 \pm 1.98 \mu \mathrm{m})$ in comparison with controls $(49.3 \pm 1.96 \mu \mathrm{m}, P=0.03)$. There was no difference in the thickness of the calcified cartilage layer between genistein treated $(18.6 \pm 1.16 \mu \mathrm{m})$ and control mice $(21.0 \pm 1.14 \mu \mathrm{m}, P=0.20)$. Data are shown as mean \pm 2 SE.

Abbreviation: SE, standard error.

rates, mimicking the phenotype seen in human diabetic patients. ${ }^{66}$ Although leptin-deficient mice that undergo leptin treatment recover osteogenic capabilities, human diabetic patients are often found to have hyperleptinemia and are nonresponsive to leptin treatments due to leptin resistance, rendering leptin an ineffective antidiabetic treatment. ${ }^{67,68}$

ERT is another mode of treatment that has been considered due to its effectiveness at ameliorating hyperandrogenicity and improving glucose homeostasis and lipoprotein profile in postmenopausal women with T2DM. ${ }^{69}$ ERT has also been documented as reducing or reversing postmenopausal bone loss and reducing the risk of OA..$^{21-24}$ However, due to the many risk factors that have been linked to chronic ERT, there has been increased interest and research on the effects of phytoestrogens as a potential antidiabetic treatment. ${ }^{29,30}$ Previous nutritional intervention studies performed on animals and humans suggest that ingestion of phytoestrogens found in soy products can improve glucose control and insulin resistance. ${ }^{70}$ Genistein is a phytoestrogen that has been suggested to be a potential natural antidiabetic agent that directly modulates pancreatic $\beta$-cell function via activation of the cAMP/PKA-dependent ERK1/2 signaling pathway as well as positively affect bone formation. ${ }^{41,42,71}$ Increased BMD has been seen with genistein treatment in previous animal studies along with increased BMD in postmenopausal women with phytoestrogen treatment. ${ }^{44,45,47-50}$ Genistein has also been noted to have a unique role in not only dampening osteoclastic markers but also stimulating osteoblastic markers in comparison with other available osteoporosis therapies that simply inhibit osteoclastic markers. ${ }^{46}$ The aim of our study was to examine the effect of dietary genistein treatment on attenuating bone loss in ob/ob mice. This is the first known study to examine the effects of genistein treatment on bone in the diabetic phenotype.

Genistein treatment did improve some indicators of bone strength in the ob/ob-treated mice of our study, but had little effect on others. Bone geometry did not adapt in a manner that improved cross-sectional geometric indicators of resistance to bending or torsional loads as indicated by a lack of significant differences in $I_{\max }, I_{\min }$, and $J$. However, mice fed a genistein-rich diet demonstrated significantly greater maximum radius of the tibia from the geometric mean, MaxRad, suggesting increased periosteal growth at the tibial midshaft. Additionally, MAr/TtAr was significantly decreased in genistein-treated groups, suggesting endosteal growth reduced the size of the medullary cavity. It is unclear how these findings may translate to humans. Several clinical trials of genistein treatment in postmenopausal women have reported no effect on bone growth or maintenance..$^{34,35}$ However, we did not directly measure genistein consumption by the ob/ob mice, so it is unknown how genistein intake in our study compares to that of the postmenopausal women in these studies. Additionally, female subjects in these studies were not obese diabetics, potentially confounding direct comparisons with our findings. Finally, ob/ob mice are hyogonadal, and it is unclear if the estrogen-like effects of genistein treatment on bone are directly related to the diabetic state. More research is needed to determine how our findings translate to human T2DM patients.

Cartilage has been documented as an estrogen-targeted tissue, suggesting that phytoestrogens could pose as a potential treatment for $\mathrm{OA}^{72}$ The effect of genistein on cartilage has minimally been explored in the literature. To our knowledge, this is the first known study to examine the effect of genistein on cartilage in ob/ob mice. Our study found that genistein treatment significantly reduced growth plate thickness, but did not reduce tibial length. This is consistent with the findings of the recent study that the expression of the main components of the extracellular matrix cartilage (collagen type II and aggrecan) and chondrocyte proliferation decreased significantly in genistein-treated mice. ${ }^{73}$ This is most likely due to genistein competing with local estrogen, leading to a decreased need for autocrine estrogen in cartilage metabolism. ${ }^{24}$ Since genistein is a phytoestrogen and has a weaker effect, this leads to suppression of extracellular matrix synthesis and chondrocyte proliferation. Although the growth plate differences we identified between treatment groups were not associated with decreases in tibial length, any treat- 
ment that impairs growth in diabetic children would warrant caution. If further investigation links genistein treatment to impaired growth due to disruption of the growth plate, its clinical value as a treatment for T2DM would diminish.

The results of our investigation support the hypothesis that genistein may slightly attenuate bone fracture risks seen in T2DM. Genistein treatment at $600 \mathrm{mg} / \mathrm{kg}$ increased periosteal and endosteal growth and led to greater cortical bone mass relative to total area of the midshaft cross-section. However, genistein treatment did not promote growth of growth plate cartilage.

\section{Acknowledgments}

We thank Ms Monica Castro, Ms Kelly Ezell, and Ms Lana Leung for their help. We also wish to thank Midwestern University, Diabetes Action Research and Education Foundation, and Soy Health Research Program, which helped fund this research.

\section{Disclosure}

The authors report no conflicts of interest in this work.

\section{References}

1. Ogden CL, Carroll MD, Kit BK, Flegal KM. Prevalence of childhood and adult obesity in the United States, 2011-2012. JAMA. 2014;311:806-814.

2. de Liefde II, van der Klift M, de Laet CE, van Daele PL, Hofman A, Pols HA. Bone mineral density and fracture risk in type-2 diabetes mellitus: the Rotterdam Study. Osteoporos Int. 2005;16:1713-1720.

3. Dede AD, Tournis S, Dontas I, Trovas G. Type 2 diabetes mellitus and fracture risk. Metabolism. 2014;63:1480-1490.

4. Bonds DE, Larson JC, Schwartz AV, et al. Risk of fracture in women with type 2 diabetes: the Women's Health Initiative Observational Study. J Clin Endocrinol Metab. 2006;91:3404-3410.

5. Garg R, Chen Z, Beck T, et al. Hip geometry in diabetic women: implications for fracture risk. Metabolism. 2012;61:1756-1762.

6. Burghardt AJ, Issever AS, Schwartz AV, et al. High-resolution peripheral quantitative computed tomographic imaging of cortical and trabecular bone microarchitecture in patients with type 2 diabetes mellitus. J Clin Endocrinol Metab. 2010;95:5045-5055.

7. Leslie WD, Rubin MR, Schwartz AV, Kanis JA. Type 2 diabetes and bone. J Bone Miner Res. 2012;27:2231-2237.

8. Hamrick MW, Ferrari SL. Leptin and the sympathetic connection of fat to bone. Osteoporos Int. 2008;19:905-912.

9. Wauters M, Considine RV, Yudkin JS, Peiffer F, De Leeuw I, Van Gaal LF. Leptin levels in type 2 diabetes: associations with measures of insulin resistance and insulin secretion. Horm Metab Res. 2003;35:92-96.

10. Donahue RP, Prineas RJ, Donahue RD, et al. Is fasting leptin associated with insulin resistance among nondiabetic individuals? The Miami Community Health Study. Diabetes Care. 1999;22:1092-1096.

11. Zimmet P, Boyko EJ, Collier GR, de Courten M. Etiology of the metabolic syndrome: potential role of insulin resistance, leptin resistance, and other players. Ann N Y Acad Sci. 1999;892:25-44.

12. Lewis GF, Carpentier A, Adeli K, Giacca A. Disordered fat storage and mobilization in the pathogenesis of insulin resistance and type 2 diabetes. Endocr Rev. 2002;23:201-229.
13. Sethi JK, Vidal-Puig AJ. Thematic review series: adipocyte biology. Adipose tissue function and plasticity orchestrate nutritional adaptation. J Lipid Res. 2007;48:1253-1262.

14. Correia ML, Rahmouni K. Role of leptin in the cardiovascular and endocrine complications of metabolic syndrome. Diabetes Obes Metab. 2006;8:603-610.

15. Gu X, Chen Z, El Bayoumy I. Serum leptin levels in obese women with and without type 2 diabetes mellitus. Minerva Endocrinol. 2014;39:223-229.

16. Reinehr T, Woelfle J, Wiegand $\mathrm{S}$, et al. Leptin but not adiponectin is related to type 2 diabetes mellitus in obese adolescents. Pediatr Diabetes. Epub 2015 Apr 16.

17. Hamrick MW, Pennington C, Newton D, Xie D, Isales C. Leptin deficiency produces contrasting phenotypes in bones of the limb and spine. Bone. 2004;34:376-383.

18. Muzzin P, Eisensmith RC, Copeland KC, Woo SL. Correction of obesity and diabetes in genetically obese mice by leptin gene therapy. Proc Natl Acad Sci USA. 1996;93:14804-14808.

19. Kishida Y, Hirao M, Tamai N, et al. Leptin regulates chondrocyte differentiation and matrix maturation during endochondral ossification. Bone. 2005;37:607-621.

20. Bartell SM, Rayalam S, Ambati S, et al. Central (ICV) leptin injection increases bone formation, bone mineral density, muscle mass, serum IGF-1, and the expression of osteogenic genes in leptin-deficient ob/ob mice. J Bone Miner Res. 2011;26:1710-1720.

21. Fitzpatrick LA. Estrogen therapy for postmenopausal osteoporosis. Arq Bras Endocrinol Metabol. 2006;50:705-719.

22. Nevitt MC, Cummings SR, Lane NE, et al. Association of estrogen replacement therapy with the risk of osteoarthritis of the hip in elderly white women. Arch Intern Med. 1996;156:2073-2080.

23. Zhang Y, McAlindon TE, Hannan MT, et al. Estrogen replacement therapy and worsening of radiographic knee osteoarthritis: the Framingham Study. Arthritis Rheum. 1998;41:1867-1873.

24. Spector TD, Nandra D, Hart DJ, Doyle DV. Is hormone replacement therapy protective for hand and knee osteoarthritis in women? The Chingford Study. Ann Rheum Dis. 1997;56:432-434.

25. Pelleymounter MA, Baker MB, McCaleb M. Does estradiol mediate leptin's effects on adiposity and body weight? Am J Physiol. 1999;276: 955-963.

26. Beral V, Bull D, Doll R, et al. Breast cancer and hormone replacement therapy: collaborative reanalysis of data from 51 epidemiological studies of 52, 705 women with breast cancer and 108, 411 women without breast cancer. Lancet. 1997;350:1047-1059.

27. Beral V, Banks E, Reeves G, et al. Breast cancer and hormonereplacement therapy: the Million Women Study. Lancet. 2003;362: 1330-1331.

28. Kim HK, Nelson-Dooley C, Della-Fera MA, et al. Genistein decreases food intake, body weight, and fat pad weight and causes adipose tissue apoptosis in ovariectomized female mice. J Nutr. 2006;136: 409-414.

29. Clarkson TB, Anthony MS, Williams JK, Honoré EK, Cline JM. The potential of soybean phytoestrogens for postmenopausal hormone replacement therapy. Proc Soc Exp Biol Med. 1998;217: 365-368.

30. Brzezinski A, Debi A. Phytoestrogens: the "natural" selective estrogen receptor modulators? Eur J Obstet Gynecol Reprod Biol. 1999;85:47-51.

31. Atteritano M, Mazzaferro S, Bitto A, et al. Genistein effects on quality of life and depression symptoms in osteopenic postmenopausal women: a 2-year randomized, double-blind, controlled study. Osteoporos Int. 2014;25:1123-1129.

32. Bouker KB, Hilakivi-Clarke L. Genistein: does it prevent or promote breast cancer? Environ Health Perspect. 2000;108:701-708.

33. Seo HS, DeNardo DG, Jacquot Y, et al. Stimulatory effect of genistein and apigenin on the growth of breast cancer cells correlates with their ability to activate ER alpha. Breast Cancer Res Treat. 2006;99:121-134. 
34. Levis S, Strickman-Stein N, Ganjei-Azar P, Xu P, Doerge DR, Krischer J. Soy isoflavones in the prevention of menopausal bone loss and menopausal symptoms: a randomized, double-blind trial. Arch Intern Med. 2011;171:1363-1369.

35. Tai TY, Tsai KS, Tu ST, et al. The effect of soy isoflavone on bone mineral density in postmenopausal Taiwanese women with bone loss: a 2-year randomized double-blind placebo-controlled study. Osteoporos Int. 2012;23:1571-1580.

36. Hu XJ, Xie MY, Kluxen FM, Diel P. Genistein modulates the anti-tumor activity of cisplatin in MCF-7 breast and HT-29 colon cancer cells. Arch Toxicol. 2014;88:625-635.

37. Atteritano M, Pernice F, Mazzaferro S, et al. Effects of phytoestrogen genistein on cytogenetic biomarkers in postmenopausal women: 1 year randomized, placebocontrolled study. Eur J Pharmacol. 2008;589:22-26.

38. Marini H, Bitto A, Altavilla D, et al. Breast safety and efficacy of genistein aglycone for postmenopausal bone loss: a follow-up study. J Clin Endocrinol Metab. 2008;93:4787-4796.

39. Bitto A, Polito F, Atteritano M, et al. Genistein aglycone does not affect thyroid function: results from a three-year, randomized, double-blind, placebocontrolled trial. J Clin Endocrinol Metab. 2010;95:3067-3072

40. Russo M, Russo GL, Daglia M, et al. Understanding genistein in cancer: the "good" and the "bad" effects: a review. Food Chem. 2016;196:589-600.

41. McClain RM, Wolz E, Davidovich A, Edwards J, Bausch J. Reproductive safety studies with genistein in rats. Food Chem Toxicol. 2007;45:1319-1332.

42. Messina M, Ho S, Alekel DL. Skeletal benefits of soy isoflavones: a review of the clinical trial and epidemiologic data. Curr Opin Clin Nutr Metab Care. 2004;7:649-658.

43. McCarty MF. Isoflavones made simple - genistein's agonist activity for the beta-type estrogen receptor mediates their health benefits. Med Hypotheses. 2006;66:1093-1114.

44. Chanawirat A, Khemapech S, Patumraj S, Siriviriyakul P. Genistein replacement therapy on endothelial dysfunction and bone loss in bilateral ovariectomized rats. Clin Hemorheol Microcirc. 2006;34: 309-314.

45. Erlandsson MC, Islander U, Moverare S, Ohlsson C, Carlsten H. Estrogenic agonism and antagonism of the soy isoflavone genistein in uterus, bone and lymphopoiesis in mice. APMIS. 2005;113:317-323.

46. Bitto A, Burnett BP, Polito F, et al. Effects of genistein aglycone in osteoporotic, ovariectomized rats: a comparison with alendronate, raloxifene and oestradiol. Br J Pharmacol. 2008;155:896-905.

47. Chen YM, Ho SC, Lam SS, Ho SS, Woo JL. Beneficial effect of soy isoflavones on bone mineral content was modified by years since menopause, body weight, and calcium intake: a double-blind, randomized, controlled trial. Menopause. 2004;11:246-254.

48. Wu J, Oka J, Higuchi M, et al. Cooperative effects of isoflavones and exercise on bone and lipid metabolism in postmenopausal Japanese women: a randomized placebo-controlled trial. Metabolism. 2006;55:423-433.

49. Morabito N, Crisafulli A, Vergara C, et al. Effects of genistein and hormone replacement therapy on bone loss in early postmenopausal women: a randomized double blind placebo - controlled study. J Bone Miner Res. 2002;17:1904-1912.

50. Marini H, Minutoli L, Polito F, et al. Effects of the phytoestrogen genistein on bone metabolism in osteopenic postmenopausal women: a randomized trial. Ann Intern Med. 2007;146:839-847.

51. Claassen H, Briese V, Manapov F, Nebe B, Schünke M, Kurz B. The phytoestrogens daidzein and genistein enhance the insulin-stimulated sulfate uptake in articular chondrocytes. Cell Tissue Res. 2008;333: 71-79.

52. Kim RP, Edelman SV, Kim DD. Musculoskeletal complications of diabetes mellitus. Clin Diabetes. 2001;19:132-135.
53. Bergink AP, van Meurs JB, Loughlin J, et al. Estrogen receptor $\alpha$ gene haplotype is associated with radiographic osteoarthritis of the knee in elderly men and women. Arthritis Rheum. 2003;48:1913-1922.

54. Spector TD, Campion GD. Generalised osteoarthritis: a hormonally mediated disease. Ann Rheum Dis. 1989;48:523.

55. Ushiyama T, Ueyama H, Inoue K, Nishioka J, Ohkubo I, Hukuda S. Estrogen receptor gene polymorphism and generalized osteoarthritis. J Rheumatol. 1998;25:134-137.

56. Al-Nakkash L, Clarke LL, Rottinghaus GE, Chen YJ, Cooper K, Rubin LJ. Dietary genistein stimulates anion secretion across female murine intestine. J Nutr. 2006;136:2785-2790.

57. Barnes S, Sfakianos J, Coward L, Kirk M. Soy isoflavonoids and cancer prevention. Underlying biochemical and pharmacological issues. $A d v$ Exp Med Biol. 1996;401:87-100.

58. Sfakianos J, Coward L, Kirk M, Barnes S. Intestinal uptake and biliary excretion of the isoflavone genistein in rats. J Nutr. 1997;127: $1260-1268$.

59. Xu X, Wang HJ, Murphy PA, Cook L, Hendrich S. Daidzein is a more bioavailable soymilk isoflavone than is genistein in adult women. J Nutr. 1994; $124: 825-832$.

60. Hsieh CY, Santell RC, Haslam SZ, Helferich WG. Estrogenic effects of genistein on the growth of estrogen receptor-positive human breast cancer (MCF-7) cells in vitro and in vivo. Cancer Res. 1998;58:3833-3838

61. Ducy P, Amling M, Takeda S, et al. Leptin inhibits bone formation through a hypothalamic relay: a central control of bone mass. Cell. 2000;100:197-207.

62. Burguera B, Hofbauer LC, Thomas T, et al. Leptin reduces ovariectomyinduced bone loss in rats. Endocrinology. 2001;142:3546-3553.

63. Takeda S, Elefteriou F, Levasseur R, et al. Leptin regulates bone formation via the sympathetic nervous system. Cell. 2002;111: 305-317.

64. Liu LF, Shen WJ, Ueno M, Patel S, Azhar S, Kraemer FB. Age-related modulation of the effects of obesity on gene expression profiles of mouse bone marrow and epididymal adipocytes. PLoS One. 2013;8:e72367.

65. Zhang J, Li T, Xu L, et al. Leptin promotes ossification through multiple ways of bone metabolism in osteoblast: a pilot study. Gynecol Endocrinol. 2013;29:758-762.

66. Turner RT, Kalra SP, Wong CP, et al. Peripheral leptin regulates bone formation. J Bone Miner Res. 2013;28:22-34.

67. Mittendorfer B, Horowitz JF, DePaoli AM, McCamish MA, Patterson BW, Klein S. Recombinant human leptin treatment does not improve insulin action in obese subjects with type 2 diabetes. Diabetes. 2011; 60:1474-1477.

68. Andersson B, Mattsson LA, Hahn L, et al. Estrogen replacement therapy decreases hyperandrogenicity and improves glucose homeostasis and plasma lipids in postmenopausal women with noninsulin-dependent diabetes mellitus. J Clin Endocrinol Metab. 1997;82:638-643.

69. Bhathena SJ, Velasquez MT. Beneficial role of dietary phytoestrogens in obesity and diabetes. Am J Clin Nutr. 2002;76:1191-1201.

70. Fu Z, Zhang W, Zhen W, et al. Genistein induces pancreatic $\beta$-cell proliferation through activation of multiple signaling pathways and prevents insulin-deficient diabetes in mice. Endocrinology. 2010;151:3026-3037

71. Naaz A, Yellayi S, Zakroczymski MA, et al. The soy isoflavone genistein decreases adipose deposition in mice. Endocrinology. 2003;144: 3315-3320.

72. Yu SB, Wang MQ, Li YQ, et al. The effects of age and sex on the expression of oestrogen and its receptors in rat mandibular condylar cartilages. Arch Oral Biol. 2009;54:479-485.

73. Yu SB, Xing XH, Dong GY, Weng XL, Wang MQ. Excess genistein suppresses the synthesis of extracellular matrix in female rat mandibular condylar cartilage. Acta Pharmacol Sin. 2012;33:918-923. 
Diabetes, Metabolic Syndrome and Obesity: Targets and Therapy

Dovepress

\section{Publish your work in this journal}

Diabetes, Metabolic Syndrome and Obesity: Targets and Therapy is opinion and commentaries are all considered for publication. The an international, peer-reviewed open-access journal committed to the rapid publication of the latest laboratory and clinical findings in the fields of diabetes, metabolic syndrome and obesity research. Original research, review, case reports, hypothesis formation, expert manuscript management system is completely online and includes a very quick and fair peer-review system, which is all easy to use. Visit http://www.dovepress.com/testimonials.php to read real quotes from published authors.

Submit your manuscript here: http://www.dovepress.com/diabetes-metabolic-syndrome-and-obesity-targets-and-therapy-journal 